\title{
Alexandre Dumas, Lettres de Capri
}

\section{Lise Sabourin}

\section{OpenEdition}

\section{Journals}

Édition électronique

URL : https://journals.openedition.org/studifrancesi/3149

DOI : 10.4000/studifrancesi.3149

ISSN : 2427-5856

Éditeur

Rosenberg \& Sellier

\section{Édition imprimée}

Date de publication : 1 juillet 2013

Pagination : 472

ISSN : 0039-2944

\section{Référence électronique}

Lise Sabourin, «Alexandre Dumas, Lettres de Capri », Studi Francesi [En ligne], 170 (LVII | II) | 2013, mis en ligne le 30 novembre 2015, consulté le 02 février 2023. URL : http://journals.openedition.org/ studifrancesi/3149; DOI : https://doi.org/10.4000/studifrancesi.3149

\section{Ce document a été généré automatiquement le 2 février 2023.}

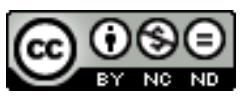

Creative Commons - Attribution - Pas d'Utilisation Commerciale - Pas de Modification 4.0 International - CC BY-NC-ND 4.0

https://creativecommons.org/licenses/by-nc-nd/4.0/ 


\title{
Alexandre Dumas, Lettres de Capri
}

\author{
Lise Sabourin
}

\section{RÉFÉRENCE}

ALEXANDRE DUMAS, Lettres de Capri, édition établie, préfacée et annotée par Claude SCHOPP, Paris, Éditions La Bibliothèque, 2012, pp. 155.

1 Chez cet éditeur spécialisé dans les livres rares, Claude Schopp publie, avec notes et notices nominales, les Lettres de Caprée parues dans «La Presse» du 12 au 25 août 1836, sans nom d'auteur: sa préface (pp. 5-28) explique le faisceau d'indices qui lui permet de les attribuer à Alexandre Dumas.

Il se fonde notamment sur deux feuillets manuscrits conservés aux Archives nationales de Prague, issus du legs effectué par Marie Dumas au prince de Metternich pour son musée dumasien de Kungsvart en Bohême, où il reconnaît le début de la lettre datée du 18 juillet, prêtée à un scripteur dénommé Edmond, comme le Dantès de Monte-Cristo. Dumas avait rédigé déjà deux articles sur le théâtre pour «La Presse» en juillet 1836: il retranscrit donc les souvenirs de son voyage italien de juillet 1835, en compagnie de Jadin, dans ces Lettres de Capri qui paraissent au moment de la visite parisienne du roi des Deux Siciles, Ferdinand II, en quête d'une nouvelle épouse. L'on comprend que Dumas, employé du duc d'Orléans, en passe d'être intime avec Fernand, le fils du futur roi Louis-Philippe, n'ait pu signer ces violentes diatribes au moment précis où la famille princière recevait dans sa résidence d'été de Neuilly le roi veuf qu'on envisageait de marier à la fille de Marie-Amélie. Heureusement il n'en fut rien, et Marie, la princesse artiste, évita ce mariage avec celui qui apparaît comme un rustre épuisé par le tourisme protocolaire qu'on lui impose. Dumas relate les vexations subies par les voyageurs français dans les États pontificaux et vitupère contre les turpitudes des Bourbons de Naples avec une virulence due au souvenir des mauvais traitements subis par son père, capturé à Tarente en 1799 et mort des sévices infligés dans les prisons de la reine Marie-Caroline. La vendetta d'orphelin inconsolable en Dumas, également visible dans Le Corricolo, I Borboni di Napoli et ses Mémoires, s'accomplit sur la descendance de la sœur 
de Marie-Antoinette qui, en pleine reconquête de son royaume, avait puni les Français de la proclamation de la République parthénopéenne. 